\title{
Law and Social Affairs; Analysis of the Factors of Early Marriage in Nibung Village, Koba District, Central Bangka Regency
}

\author{
Arifin Faqih Gunawan \\ arifinfaqih@gmail.com \\ Department Sociology and Criminal Law \\ School of Law Pertiba Pangkalpinang
}

\begin{abstract}
The Marriage Law, number 1 of 1974 gives the minimum age limit for a person to be allowed to marry if a man has reached the age of 19 years and a woman has reached the age of 16 years. This study explains the factors influence the occurrence of early marriage in Nibung Village, Koba District, Central Bangka Regency. The purpose of this study is to identify the factors that influence the occurrence of early marriage in Nibung Village, and to see the public's understanding of early marriage from the side of the Law. The results of this study indicate that there are 2 categories of factors that influence early marriage. There are two positive trend factors which are parents' perceptions \&culture and beliefs. There are also two negative trend factors which are intellectuality and the value of virginity.
\end{abstract}

Keywords: Factors, Early Marriage, Nibung Village, Central Bangka,

\section{INTRODUCTION}

The age of marriage in some regions and even some countries continues to be an interesting debate. The government's desire for the people to marry at a mature age to make a quality family life, in reality, is not as easy as it was formulated. (UNICEF;2014) The fundamental problem for the community is about the perception of mature age where it is not based on their age but based on their "natural sign" regarding the religion. (Hossain, $M$ : 2013). For example the maturity sign for woman are marked by menstruation and men are marked with "Wet dreams".

Aside from the rules of religion, some cultures that prefer to marry off their children at young age isone of the reason for many early marriages in certain communities. For parents, allowingtheir children to get married at young age at least reduce the moral burden where children sometimes take excessive actions in relationships with the opposite sex.

In Indonesia, the provisions of the Law state that the adult age is 21 years. However, in terms of the age limit, someone below 18 years listed as children in the child protection law. (See Law Number 35 Year 2004) In contrast to the UUPA, the Marriage Act, Number 1 of 1974 gives the minimum age limit for a person to be allowed to marry if a man has reached the age of 19 years and a woman has reached the age of 16 . (See Article 7 (1) Law Number 1 Year 1974)

At this age, marriage can occur with a note that you must get permission from a parent or guardian. (See Article 7 (2) Law Number 1 Year 1974) While the marriage of "under age" children according to the provisions above, is also still permissible as long as there is permission from the Religious Court. (See Article 7 (5) Law Number 1 Year 1974). The Religious Court will give a decision on biological, psychological and psychological maturity whether a child is allowed to get married or not. This provision is a gap for people to marry off their underage children.(ibid)

In some communities in Nibung Village, Koba Subdistrict, Central Bangka Regency, early marriage occurred due to the inherent culture of certain tribes who 
viewed early marriage as a natural thing. On the other hand, religious teachings related to understanding figh are so stron. And it is not easy to change the paradigm of society in terms of marriage. (Interview: Muhammad, 09-26-1818). In addition to these two factors, there are certainly many other factors that influence the occurrence of early marriage.

A problem that arises in society is not because of one or two factors only but also it may be an accumulation of several things such as beliefs, culture, social and psychological conditions. These things certainly become interesting if we explore further how the community, including government officials in RT, RW and villages respond to these factors (Especially related to the marriage law and child protection law). This research needs to be done due to these reasons. The research focuses on what factors influence the occurrence of early marriage in Nibung Village.

\section{Research methods}

This research is a field research, because the object and the data needed in this study is in the form of certain cases involving certain regions (Ronny Hanitijo Soemitro, 1983: 49) located in Nibung Village, Koba District, Central Bangka Regency. This study is descriptive analytic, which is the research that explains the existing reality and analyzes the factors that influence the occurrence of early marriage.

The method of data collection in this study was carried out by distributing questionnaires to village officials and the community. Interviews were then conducted with several religious leaders, community leaders and some people who experienced early marriages. Then the data that has been collected was analyzed by the quality method, which is an analysis of the data about the factors that influence early marriage. The data obtained will be described according to the systematic discussion and will then be analyzed qualitatively with deductive-inductive reasoning.

\section{Main discussion; Early Married Factors and Problem Analysis}

Some of the common factors that led to the occurrence of early marriage in studies of early marriage was confirmed to the community, especially village officials, to further analyze the understanding from the legal side. This analyst needs to be done to get an objective picture of people's understanding and the actions that need to be taken by both law enforcement officials and government institutions.

\section{a. Cultural and Belief Factors}

Early marriage is not a problem in a particular culture. (UNICEF; 2011) They consider that marrying off children (especially girls) faster is something that is usually done by parents. Sometimes, there is an assumption that married women over the age of 20 are spinsters. (Hanum; 1997). On the other hand, marrying off their children faster is one of the way to prevent free sex among teenagers by the parents. According to customs, marrying a child after graduating is a normal thing and girls may not pursue higher educationbecause it can lead to spinsters.

There are $37 \%$ of Nibung's people agree that marrying of the children faster are usually done by the parents, while $63 \%$ choose disagree (see in the results of the questionnaire; 2018). This level of understandingshows that early marriage is not a tradition among village officials although several people believe that this action is still being carried out.

When the people was asked whether marrying a child over the age of 20 is considered a spinster or not,there are only $19 \%$ answered yes, while $81 \%$ answered no. (ibid) This means the understanding of the community has begun to open up in matters of marital age. And it is similar with this case, which is the understandingthat marrying a child after graduating from school is not a tradition. At least only $19 \%$ answered yes while the rest answered no. 
P-ISSN 2622-8831

Berumpun Journal: An International Journal of Social, Politics and Humanities Vol. 2 No. 1 March 2019

The Nibung community, especially among government officials was awarethat nowadays the culture to believe stopping girls' education can prevent them becoming spinsters has been abandoned.(ibid) At least only one person answers yes, the restanswer no. This means that there is no belief in society about that kind of culture.

Even though the understanding of the age of marriage is good enough, howeverthe community still believes that marrying a child faster is one of the wayby parents to prevent children from free sex. $50 \%$ answered yes and $50 \%$ answeredno. Half of the people who still believe that early marriage can prevent free sex think that it is a form of concern for parentsregarding the behavior of the younger generation in conducting relationships. (ibid)

While those who do not believe that early marriage is the top solutionto prevent free sex shows that there may be other alternatives. This situation shows that public awareness in term of the cultureto marrying off a child is good enough even though there are still concerns about teenager's activity who tend to make parents marry off children at an early age.

Apparently, this concern is in line with the statement by religious leadersin one of the village area that questioned the urgency of limiting the age of marriage. If the case is in contrast with reality, the children who were not old enough may do the free sex. Regarding the statutory provisions concerningthe age of marriage (Article 6 of the Marriage Law), the community of Nibung Village generally alreadyunderstand about the age limit of marriage, even though some people still questioned the purpose of the restriction. The legal awareness of community is pretty good in this place.

Then, the solution that must be done by government officials in the regency isthey must be more aware of the government's goalslimit regarding the age of marriage in such a way. Collaboration with other related agenciesand also religious institutions can be done to maximize the effort.

\section{b. Factor of knowledge and intellectuality}

The Nibung community realized that marriage is a sacred relationshipbetween men and women who are legal according to religion and have sufficient age. When they are being asked about this understanding, the respondents all agreed and no one denied it.

When they are being asked whether low knowledge regarding the understanding of marriage is a factor in the occurrence of marriage at a young age, 75\%the respondent answered yes, while the rest answered no and only one person answereddo not know. (ibid) This answer certainly reinforces the initial understanding of the education level is a weakness of society in building human resources. This result confirms that even though marital age awareness is good,but the level of understanding regarding the importance of marriage is still low. So that early marriage is still very likely to occur in society.

Early marriage is also a factor in the occurrence of juvenile delinquency. (Puspitasari; 2006) The correlation between early marriages and juvenile delinquency is that the occurrence of early marriages where adolescents who are not yet mentally, physically and knowledgeably married are required to lead a family life, then they must give birth and take care of children and family. While the level of readiness is low, resulting in the teenager being unable to take care of the child well and the children grow up in the condition of parents like this, it certainly give impacts on the emotional and mental development of the child.

When they are being asked whether there is a relationship between juvenile delinquency and unpreparedness of parents to educate children because they were married at an early age, $88 \%$ answered yes. This means that the community is very aware of the impact of early marriage for future child development. Similarly, when we asked whether early marriage can reduce family harmony (this is caused by 
P-ISSN 2622-8831

Berumpun Journal: An International Journal of Social, Politics and Humanities Vol. 2 No. 1 March 2019

unstable emotions, young blood fluctuations and immature ways of thinking), $88 \%$ of respondents answered yes. The respondents' intellectuality in this period is quite good.

Regarding the age limit of marriage that has been established by law, the respondent's understanding are varies. $81 \%$ of respondents believe that the ideal age for marriage is 21-25 years. (Questionnaire, ibid) However, when we asked whether the public was aware that the law stipulates the minimum age of marriage is 19-year-old for men and 16-year-old for women, the respondents who answered yes only $50 \%$. This means that only half of the respondents who know, and the rest are not.

Unlike the case when we asked whether the respondent knew about the Child Protection Act (about the age limit for children before reach adult state is 18 years old), $69 \%$ of respondents answered yes. Respondents also believed that the determination of the age limit of marriage was due to the physical and mental readiness of the two partners. At least $75 \%$ believe that. However, whether marriage is very dependent on the situation of one's life, $56 \%$ of respondents answered yes, and the rest answered no and did not know. (ibid)

This condition shows that the knowledge of respondents in the problem of age of marriage and the age limit of children is still low. This means that there must be further guidance and socialization regarding the age limit of marriage and the category of children according to the law. Because the respondents understand the ideal age for marriage fundamentally.

The law states that marriage must be based on the agreement of the two prospective brides. This agreement only applies if the two prospective brides are 21 years old. This age in the view of law is an adult age and is called legal competent.

However, children under the age of 21 can get married as long as they get permission from their parents or guardians. This permit is only granted if the child is at least 19 years old for men and 16 years for women. Is the age of 16 and 19 years the limit of maturity of a child? It does not show a definite explanation, because they still have to ask permission from parents or guardians if they want to get married.

Parents or guardians must give permission for children to get married at least after concerning about these two factors. First, the age must be according to the minimum limits of the law. And second, they must see the physical and mental readiness and living conditions of a child. For the sake of their children, these two things should be taken seriously.

Seeing the response of the community above, it seems that public awareness regarding the marital age limits has not been absorbed as a whole. Even though the respondents answered above $50 \%$ towards a positive trend in term of the knowledge about the age of marriage and children, but it did not show a good level of understanding significantly. (ibid)

\section{c. Parents' perception of children}

Perception is someone's view of something. Parents' perceptions of children in marital problems describe parent's views towards their children. Nearly all questions asked to respondents are positive. When we asked whether following a parent's words is something a child must do, $75 \%$ of respondents answered yes. When we asked "Do parents have hope when they get married at a young age", $94 \%$ of respondents answered no. Similarly, when we asked whether parents consider that women should not be highly educated \&it is better to get married, $88 \%$ of respondents answered no. (ibid)

From the results above, it can be concluded that not many parents expect their children to marry at an early age. They hope that children can study and get married at the right time.Parents also do not consider that marrying off children at an early age will ease the economic burden of parents, $88 \%$ of respondents said no. Then when we asked whether parents who were full of conflict would negatively affect children so that children with lacked of love will do the early marriage, $63 \%$ of 
BERUIMPUN

P-ISSN 2622-8831

Berumpun Journal: An International Journal of Social, Politics and Humanities Vol. 2 No. 1 March 2019

respondents answered yes, the rest answered no and did not know.

Then when we asked whether parents consider that marriage at a young age increase the child's maturity, $94 \%$ of respondents answered no. (ibid) Parents also believe that there is no obligation to find a mate for their child, $94 \%$ of respondents believe that. Then, when we asked if a girl has got a sign of maturity, parents will immediately marry off their children, $56 \%$ of respondents answered no. But the rest answered yes and did not know. (ibid)

The result stated above shows that many parents do not really agree with early marriage. However, the condition of each child in the family is different so that the wishes of parents are sometimes not in line with reality. The reality is there are parents who allowed their children to get married even though they are not ideal enough to get married.

\begin{abstract}
Some cases of pregnancies before getting married among teenagers sometimes force parents to allow them to get married. From the view of law, if there is a case when the child must get married under the age of the law (which is 16 years for women and 19 years for men) then the parent / guardian or even the child itself is permitted to submit marriage dispensation to the court or other officials.
\end{abstract}

The limitations of marital age and the ability of this dispensation make the public's perception think that the marriage law provides alternative in the issue of marital age. However, this condition has been done to accommodate if there are certain cases where parents cannot expect the ideal age to allow the child for getting married. Article 6 paragraph 6 of the marriage law also provides a provision that parental permission for children under the age of 21 years and all provisions applies as long as it is in line with the the provisions of religion.

\section{d. Understanding the value of virginity}

The value of the virginity of modern society is not the same as traditional society, (Alice Schlegel; 1991 see also Mitike Molla; 2008) both in the city and in the village. When we asked whether being pregnant outside of marriage is common today, $69 \%$ of respondents answered no. (Questionnaire ibid) But we when asked whether teenagers tend to have premarital sex, $38 \%$ of respondents answered yes, $19 \%$ said no. (ibid) More than $43 \%$ did not answer.

When we asked whether it is normal to date at the age of teens (even for elementary school children), $50 \%$ of respondents answered yes, $25 \%$ answered no and $25 \%$ did not give answers. When we asked whether marriage will avoid free sex and satisfy the biological needs, $63 \%$ of respondents answered yes. (ibid)

From the responses above, it can be explained that, the respondents did not agree if being pregnant outside legal marriage is a common thing, even though the fact that it is happening a lot in the community. This disagreement does not mean they are ignoring the facts that it is occur in society. The proof is when it was confirmed whether there had been sexual relations among teenagers, most of the respondents believed that they had, even many did not answer. Maybe they agree but do not want to reveal or indeed they really do not know.

Early marriage starts from intercourse with the opposite sex that is too early so that children (even in elementary school) know the opposite sex like an adult. Therefore, half of the respondents confirmed that this indeed happened in the community. The solution for parents is to pay more attention to their children as early as possible.(ibid)

Understanding the value of virginity in the community tend to decline. This means that many people do not care about virginity of children before marriage. This is due to repeated events that are finally considered as normal. This is a big challenge for community leaders, religious leaders and the government to restore moral values in society. 


\section{BERUIMPUIN}

P-ISSN 2622-8831

Berumpun Journal: An International Journal of Social, Politics and Humanities Vol. 2 No. 1 March 2019

This aspect is certainly the most important obstacle to increase the minimum age for marriage if the association of adolescent children is also not limited. In relation to marriage, the community actually understands as early as possible that marriage is a physical and spiritual bond between a man and woman as husband and wife with the aim of forming a happy and eternal family based on the One Godhead (See Article 1 of the Marriage Law).

The purpose of household happiness for children must begin with good behavior in themselves, including maintaining morality in daily activity. Parents may not be able to give advice and enlighten their children if parents have made fatal mistakes in their lives, including social problems.

\section{Conclusion}

Based on the descriptions above, it can be concluded that there are several factors that affect early marriage in Nibung Village. Systematically, these factors include :

a. Cultural and belief factors. Respondents stated that the culture to marry of the children at a young age happened for a long time, although the paradigm of parents to marry off children at a young age had begun to change throughout the course of time. b. Intellectual factors lead to a negative trend where many respondents still do not understand the limits of adulthood, thus giving rise to the possibility of marriage at an early age. The solution is we must increase the socialization of marriage laws, child protection and elimination of domestic violence and an explanation of the importance of maturity in marriage from a cultural, religious and legal perspective.

c. Parents' perception of children leads to a positive trend where the majority of respondents hope that children get married at a mature age, although in certain conditions there is a dilemma whether to allow "free sex" to occur among teenagers or marry off children at an early age. The solution is the government, society, religious leaders and parents must strengthen legal, religious and moral values so that children are not affected by free sex without having to get married at an early age.

d. The value factor of virginity leads to a negative trend where respondents reject that pregnancy outside marriage is normal, but they believe that there are a lot of sexual intercourse happened before marriage among teenagers. This means that the value of virginity has decreased in terms of meaning. The solution is to strengthen religious and moral values in instilling the importance of the value of virginity. 


\section{References}

1945 Constitution of Republic Indonesia

Law No. 1 of 1974 on Marriage

Law No. 23 of 2002 amended by Law No. 35 of 2004 on Child Protection

Alice Schlegel (1991) Status, Property, and the Value on Virginity, American Anthropological Association pp. 719-734

Hanum, S.H. (1997). Perkawinan Usia Belia (Early Marriage). PPK UGM. Yogyakarta

Hossain, M. and Islam, R. (2013). Effects of socio-economic and demographic variables on age at first marriage in Bangladesh. Current Research Journal of Biological Sciences, 5(4), pp.149-152.

Mitike Molla Sisay, Yemane Berhane, Bernt Lindtjorn (2008) Traditional values of virginity and sexual behaviour in rural Ethiopian youth: Results from a cross-sectional study, Maternal and Newborn health in Ethiopia Partnership (MaNHEP)SPH, CHS,AAU-mitike

Puspitasari, F. (2006). Perkawinan Muda: Faktor-Faktor Pendorong Dan Dampaknya Terhadap Pola Asuh Keluarga: Studi Kasus Di Desa Mandalagiri, Kecamatan Leuwisari, Kabupaten Tasikmalaya (Early Marriage: The Determinants And Its Impact On Family Pattern: Case Study In Mandalagiri Village, Leuwisari District, Tasikmalaya Regency). Thesis. Faculty of Social Sciences. Semarang State University. Semarang Questionnaire; 2018

UNICEF. Working toward progress with equity under decentralization: the situation of women and children in Indonesia 2000-2010. Jakarta: UNICEF; 2011) 